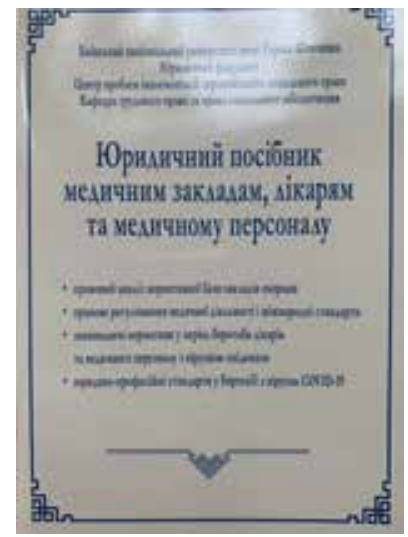

\author{
Ірина Бутирська, \\ кандичат юричичних наук, \\ асистент кафедри процесуального права \\ Чернівецького національного університету \\ імені Юрія Федьковича
}

https://doi.org/10.32782/2020-38-16

\title{
Актуальне видання на допомогу медичним закладам, лікарям та медичному персоналу ${ }^{1}$
}

На сучасному етапі Україна та і весь світ усвідомили важливість якості економічних умов і стану законодавства, яке регулює систему охорони здоров’я. Становлення в Україні правової медицини - медицини, яка належним чином регулюється відповідним законодавством та стандартами надання медичної допомоги, можливе лише завдяки консолідації зусиль медичного та юридичного співтовариства.

Питання правового регулювання надання медичних послуг завжди були актуальними. Адже в практичній діяльності медичним закладам, лікарям та медичному персоналу дуже часто доводиться вирішувати юридичні проблеми, які стосуються не лише власне медичного права, але i конституційного, адміністративного, цивільного, кримінального права тощо. Проте наскільки юристам нелегко працювати 3 медичними термінами, настільки медичним працівникам складно розбиратися у тонкощах правового регулювання діяльності у сфері охорони здоров'я. У зв'язку з цим видання, які будуть орієнтовані одночасно і на юристів, i на представників системи охорони здоров'я, завжди будуть актуальними і затребуваними суспільством.

Поширення коронавірусної хвороби (COVID-19) вплинуло на всі сфери суспільного життя. Тому актуальності набуло нормативно-правове регулювання такої ситуації, адже на державному рівні постала об'єктивна потреба прийняття низки законодавчих та підзаконних актів, які б встановлювали відповідні стандарти та протоколи поводження 3 хворими (у тому числі особами, в яких є підозра на захворювання) та лікування такої хвороби.

Представники юридичної теорії та практики оперативно оцінили актуальність наявних соціальних проблем

\footnotetext{
${ }^{1}$ Юридичний посібник медичним закладам, лікарям та медичному персоналу: закони України, науково-практичні директиви, нормативно-правові акти, юридико-професійні медичні стандарти / упор.: А.О. Селіванов, М.І. Іншин (керівники проєкту), В.П. Янишен, Ю.В. Кабенок, Я.О. Токарь. Київ : Логос, 2020. 75 с.
} 
у галузі медицини i, як наслідок, колектив провідних харківських та київських науковців та практиків на чолі з академіками Національної академії правових наук України А.О. Селівановим та M.I. Іншиним підготував та видав юридичний посібник на допомогу медичним закладам, лікарням та медичному персоналу.

У навчально-методичному посібнику висвітлено актуальні питання, які розкривають обсяг і зміст сучасних юридичних знань у сфері організації та діяльності лікарського складу і медичного персоналу, що забезпечують надання на професійній основі послуг у закладах охорони здоров’я України. У посібнику в системному порядку за критеріями набуття та поглибленого вивчення актуальних напрямів діяльності лікарського складу та медичного персоналу автори-упорядники провели правовий аналіз законів і підзаконних нормативно-правових актів, директив, міжнародних стандартів та інших актів стосовно медичних лікарських кадрів і персоналу з урахуванням особливості їх діяльності та функціонування у медичних закладах.

Підсумовуючи, зазначимо, що рецензований «Юридичний посібник на допомогу медичним закладам, лікарям та медичному персоналу» є актуальним практичним виданням, яке буде корисним як медичним працівникам, так і юристам, що практикують у галузі медичного права. 